\title{
Can leftovers from predators be reliably used to monitor marine turtle hatchling sex-ratios? The implications of prey selection by ghost crabs
}

\author{
Rui Rebelo $\cdot$ Castro Barbosa $\cdot$ José P. Granadeiro • \\ Bucar Indjai • Bruno Novais • Gonçalo M. Rosa • \\ Paulo Catry
}

Received: 24 August 2011/Accepted: 4 November 2011/Published online: 23 November 2011

(c) Springer-Verlag 2011

\begin{abstract}
In marine turtles, the sex of an individual is determined by temperatures experienced during embryonic development. Gonad histological observation is still the only reliable way to determine hatchling sex, hampering the study of reproduction and of the demographic consequences of context-dependent sex-ratios, a subject of interest in a warming planet. We investigated whether hatchling remains from predation by Ocypode cursor can be used to estimate sex-ratio trends in a green turtle rookery at Poilão, Guinea-Bissau $\left(10^{\circ} 52^{\prime} \mathrm{N}, 15^{\circ} 43^{\prime} \mathrm{W}\right)$. Sex could be readily determined in 77 and $79 \%$ of the predated
\end{abstract}

Communicated by R. Lewison.

R. Rebelo $(\bowtie) \cdot$ B. Novais · G. M. Rosa

Centro de Biologia Ambiental, Departamento de Biologia

Animal, Faculdade de Ciências da Universidade de Lisboa,

Bloco C2, Campo Grande, 1749-016 Lisbon, Portugal

e-mail: rmrebelo@fc.ul.pt

C. Barbosa

Instituto da Biodiversidade e das Áreas Protegidas,

Bissau, Guinea-Bissau

J. P. Granadeiro

CESAM, Museu Nacional de História Natural,

Universidade de Lisboa, Lisbon, Portugal

B. Indjai

Instituto Nacional de Estudos e Pesquisas, Bissau,

Guinea-Bissau

G. M. Rosa

Department of Anthropology, Durrell Institute of Conservation and Ecology, University of Kent, Canterbury, Kent, UK

P. Catry

Eco-Ethology Research Unit \& Centro de Biociências,

ISPA - Instituto Universitário, Lisbon, Portugal hatchlings in 2008 and 2009, respectively. By comparing hatchlings killed by crabs, hatchlings accidentally dying on the reefs, and live hatchlings, we show that ghost crabs select the smaller prey, but do not select according to hatchling sex, which is explained by the lack of hatchling size dimorphism in this population. The proportion of male hatchlings was $0.45 \pm 0.06$ and $0.15 \pm 0.06$ for early and late-season clutches, respectively, these differences most likely being explained by rainfall. Using leftovers from predation by crabs may be a good solution to non-invasively monitor broad trends in sex-ratios of sea turtles.

\section{Introduction}

The determination of hatchling sex by incubation temperature is a well-known phenomenon that occurs in all extant sea turtles, whereby high incubation temperatures result in the development of more females, while low temperatures yield more males (Wibbels 2003). The effect of temperature on sex determination occurs only in a relatively short period during the whole incubation. This thermo-sensitive period takes place during the second third of incubation, after which hatchling sex becomes determined (MerchantLarios et al. 1997). The effect of temperature may be dramatic, leading many clutches to develop either $100 \%$ males or females, whereas in the so called transitional range of temperatures, a mixture of males and females is produced. Included in this range, there is a temperature at which a 1:1 sex-ratio will be produced-the pivotal temperature (Wibbels 2003).

The potential impacts of the current global warming on sea turtle sex-ratios have become a growing conservation concern (Godley et al. 2002; Glen and Mrosovsky 2004; Chaloupka et al. 2008; Godley 2009; Witt et al. 2010). 
However, due to the absence of externally dimorphic characteristics or of heteromorphic sex chromosomes (Ewert and Nelson 1991), it is not possible to assess the sex of hatchlings with simple methods. More invasive methods, such as laparoscopy or hormonal assays, have proved to be effective in juveniles but not in hatchlings (Wibbels et al. 2000; Wyneken et al. 2007; but see Gross et al. 1995). Hence, the estimation of clutch sex-ratios has been based mainly in indirect methods. Several researchers have used the currently known pivotal temperatures and measurements of nest or sand temperatures for this purpose (Wibbels 2003; Glen and Mrosovsky 2004; Kamel and Mrosovsky 2006). However, these methods may provide poor sex-ratio estimates when nest temperatures fluctuate during the thermo-sensitive period, a common phenomenon in the wild, particularly when rainfall occurs. As nest temperature is negatively correlated with incubation duration, the latter parameter has also been used to estimate hatchling sex-ratios (Mrosovsky et al. 1999; Zbinden et al. 2007). Again, this method may perform poorly, as the developing embryo responds to the temperature regimes of the whole incubation period and not just of the thermosensitive period (Mrosovsky et al. 1999; Reece et al. 2002).

The histological examination of gonads is still considered to be the most accurate and reliable method to determine sex in sea turtle hatchlings and is also used to calibrate the above-mentioned indirect methods (Mrosovsky and Benabib 1990; Godley et al. 2002; Wibbels 2003; Witt et al. 2010). To the naked eye, hatchling gonads are not morphologically distinct (Miller and Limpus 2003; but see Ceriani and Wyneken 2008), consisting on a slim, tubular structure that runs alongside the ventral side of the kidneys. However, in histological sections, the gonads are clearly distinct (Miller and Limpus 2003).

Despite the reliability of this method, the necessity to kill hatchlings renders the histological examination of gonads impracticable in large scale. To overcome this difficulty, dead hatchlings recovered from their nests (either unhatched or that died during hatching and emergence) have been used to estimate sex-ratios (Godley et al. 2002; Kaska et al. 2006), but this method must be tested, as mortality during development may be biased towards one or the other sex. However, hatchlings frequently die during their short journey to the sea. Beach physiography may induce mass mortalities when hatchlings become stranded in rocks, debris or mangroves. Furthermore, hatchling predation by crabs (Tomillo et al. 2010), reptiles (Fortes et al. 1998), birds (Toland 1991) and mammals (Mendonça et al. 2010) is well documented, and several of these predators leave remains that may be collected and used. This method must also be tested, as predators may prefer one sex over the other. Furthermore, the remains of hatchlings from different clutches may be scattered on the nesting beaches, making impossible to assign hatchlings to a particular clutch.

The beaches of the Bijagós archipelago (Guinea-Bissau), in the West African coast, are one of the most important breeding grounds of the green turtle, Chelonia mydas (L., 1758). The number of clutches laid by green turtles at one of the smallest islands-Poilão-is estimated to vary between ca. 7,000 and 29,000 per year, making this island the third most important nesting site for $C$. mydas in the Atlantic and the most important location in the whole of Africa; it is also one of the twelve most important beaches for C. mydas in the world (Catry et al. 2009). At Poilão, green turtle hatchlings are frequently predated by the ghost crab Ocypode cursor (L., 1758). This crab feeds by searching debris or live prey during the night along the shoreline (Tureli et al. 2009) and is abundant on the island. Poilão has another important feature-the island is surrounded by a ring of rocks that, over most of the coastline, completely blocks access to sea to the hatchlings that emerge during the low tide. When this coincides with sunrise, the hatchlings become imprisoned in the rock crevices, which often lead to die-offs of entire broods. Given the catastrophic nature of these die-offs, it is unlikely that there is any selection for particular hatchling traits, and these animals may thus be considered a random sample of the hatchlings that are born on the island.

In this work, we tested the feasibility of using hatchlings killed by ghost crabs to estimate the sex-ratio of green turtle clutches at Poilão. We compared the size and sex of hatchlings killed by ghost crabs with the same parameters from hatchlings that died from non-selective causes, such as mass stranding on rocks or random sampling. We also compared the sizes of hatchlings that died from different causes with the size of live hatchlings. We performed these comparisons in two different seasons, so that we could also test for differences in the sex-ratio of clutches that were incubated under different thermal regimes.

\section{Materials and methods}

\section{Study area}

The 43 ha island of Poilão $\left(10^{\circ} 52^{\prime} \mathrm{N}, 15^{\circ} 43^{\prime} \mathrm{W}\right)$ is located in the João Vieira and Poilão Marine National Park, SE Bijagós Archipelago, Guinea-Bissau (Fig. 1a). The archipelago has a tropical climate, with a rainy season between May and November and peak rains in August (Fig. 1b). C. mydas nesting activity is largely coincident with the rains, occurring mainly from July to November, with a maximum in August and September (Catry et al. 2002). This study uses data collected in two periods: (1) from 9 November to 4 December 2008, a period in which we 

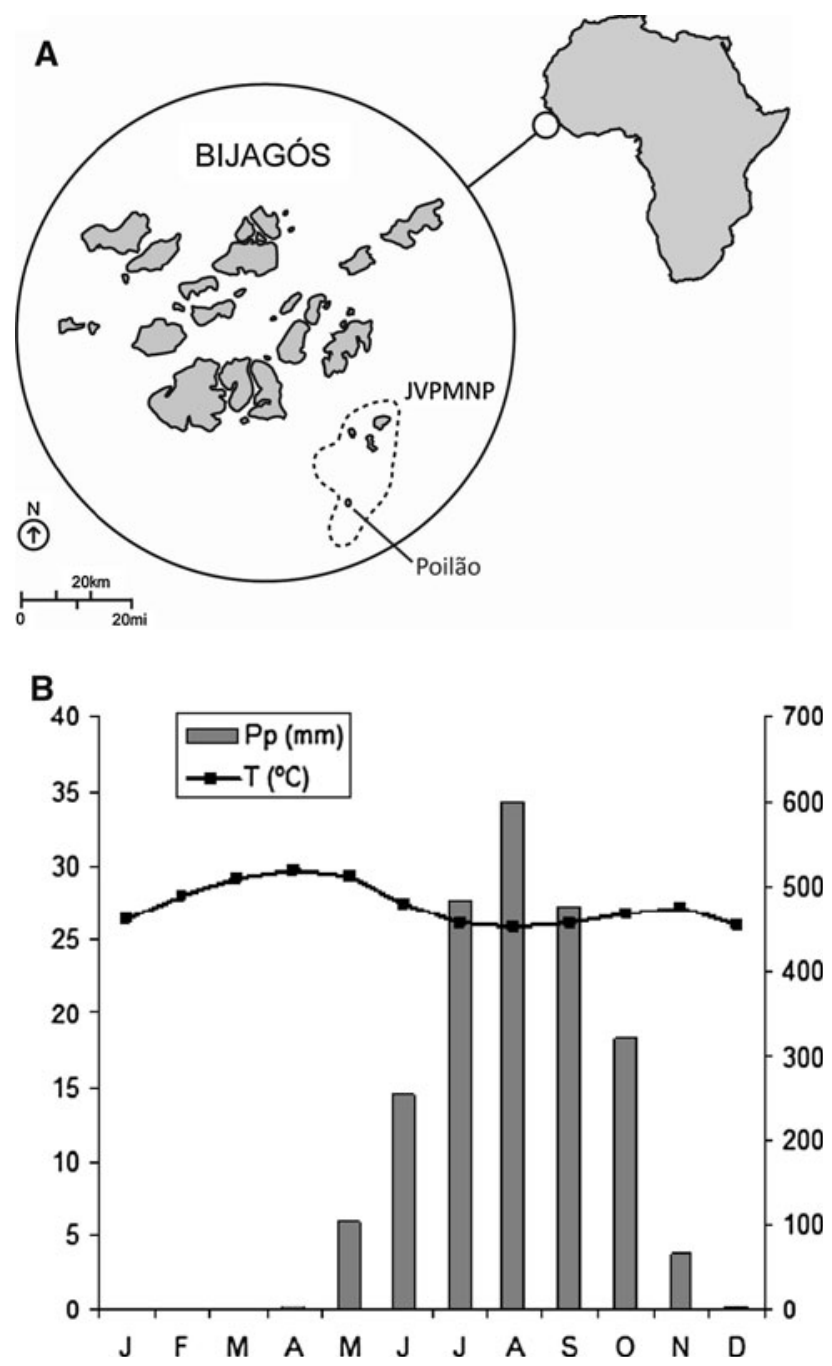

Fig. 1 a Location of the Poilão-João Viera National Marine Park and of the island of Poilão. b Ombrothermic diagram of Boke, Republic of Guinea, located at the same latitude of Poilão, about $40 \mathrm{~km}$ inland (data obtained from the World Weather Information Servicehttp://www.worldweather.org/)

estimate to have sampled hatchlings resulting from eggs laid in late September and October (based on a 49-56 days incubation period; Catry et al. 2010), (2) from 27 September to 20 October 2009, during which we estimate to have sampled hatchlings from eggs laid in late July and August (a 55-61 days incubation period). During both periods, the main nesting beaches were surveyed every night and/or early morning. These span over a total of $2.3 \mathrm{~km}$ of the $c .4 \mathrm{~km}$ coastline of the island.

\section{Sampling}

We sampled live hatchlings by randomly selecting 1-3 emergences each night. After collecting all the emerging hatchlings, 20 individuals per nest (in 2008) or 4-5 individuals per nest (in 2009) were randomly selected and kept in a plastic container for a maximum of $30 \mathrm{~min}(2008)$ and 10 min (2009), during which they were measured, being released afterwards. In 2009, we euthanized two randomly selected hatchlings from each of 40 nests, according to the procedures recommended by Stocker (2005). The total number of hatchlings euthanized represents less than $0.01 \%$ of the number estimated to have hatched on Poilão in 2009. In an attempt to compensate for our action, during the two seasons of this study, we saved from an almost certain death in excess of 1,000 hatchlings found stranded on the rocks.

To sample hatchlings killed by ghost crabs, we walked along the entire beach each day at dawn and collected those that had been killed recently. Hatchlings that died after stranding in the intertidal rocks were also collected in the early morning whenever sunrise coincided with low tides. In both cases, we took a conservative approach and considered that the small groups of dead hatchlings that were frequently found close to each other could belong to the same brood and, therefore, did not represent statistically independent observations; hatchlings were considered to belong to different clutches if they were separated by more than $100 \mathrm{~m}$ from each other along the beach.

For each hatchling, we recorded minimum straight carapace length (Bolten 1999), hereafter referred to as CL, to the nearest $0.05 \mathrm{~mm}$. We also measured plastron length, maximum straight carapace width (to the nearest $0.05 \mathrm{~mm}$ ) and body weight (to the nearest $0.5 \mathrm{~g}$ ) of all euthanized hatchlings just prior to euthanization, in order to test for differences in other body dimensions between both sexes. Hatchlings may potentially suffer rapid morphological alterations after death, due to the loss of body fluids, of internal organs (those partially eaten by ghost crabs) or by being exposed to direct sunlight. To evaluate this possibility, we measured 13 hatchlings right after being euthanized, and in the next morning, after one night of exposition to the local conditions. We further measured 12 hatchlings that had been killed and partially eaten by ghost crabs, in the early night and again in the early morning.

\section{Sex identification}

All dead hatchlings were necropsied on site in the morning of collection. The gonad/kidney complexes were removed and stored in ethanol $96^{\circ}$. Histological pieces were prepared following standard procedures: each gonad/kidney complex was embedded in resin (Technovit 7100 system) and sectioned in $3 \mu \mathrm{m}$-width slices using a Leica RM 2155 microtome. Sections were stained with toluidine blue for 1-2 min and mounted with NeoMount glue. Photographs of each section were obtained with software Irfanview, version 4.27 in a Leica DFC 290 microscope. Gonadal histology is clearly contrasting between sexes, with ovaries 
showing a compact medulla with no tubules with open lumen and a thick cortex that includes the germinal epithelium and stains heavily, while testicles show the characteristic arrangement of hollow seminiferous tubules in their medullar region and a thin cortex (Miller and Limpus 2003). Sex can also be identified by the observation of the paramesonephric ducts. At hatching, the female paramesonephric duct is constituted by epithelial columnar cells, presents an open lumen and the suspending mesentery is long and thin. On the contrary, on males, this duct begins to degenerate during incubation, and at hatching, the duct is practically devoid of lumen, and its epithelial cells are loosely packed and its suspending mesentery short and thick (Miller and Limpus 2003).

Sex was independently determined by two researchers (BN and RR), taking into account gonadal and/or paramesonephric ductal structures. We prepared one gonad/ kidney complex per individual and proceeded to the second when the first did not enable sex identification. We further sectioned both complexes for 19 hatchlings to check for consistency in sex attribution.

\section{Statistical analyses}

To account for potential dependency among observations within a clutch, we fitted Generalized Linear Mixed Models (GLMM, fitted by maximizing the restricted log-likelihood), assuming a normal distribution and an identity link function. GLMM's were used to test for differences in each body dimension among years and among hatchling categories (killed by ghost crabs, stranded on the rocks and alive), using clutch as a random factor. In order to test for sexual differences in body size, we selected a single individual from each clutch, with the exception of the cases when a brood contained both sexes (identified in rock-stranded or euthanized hatchlings), in which case both a male and female hatchling were selected. These data were analysed with a two-way ANOVA, using sex and year as fixed factors. The same approach was used to test for sexual differences in carapace width and body weight, using the 2009 sample of euthanized hatchlings and a $t$ test. To test for post-mortem alterations in body dimensions, we used a paired $t$ test.

Finally, in order to compare the sex-ratios among hatchling categories and years, we used a generalized linear model (GLM) assuming a binomial distribution (and a logit link function) setting the proportion of males within each clutch as a response.

The significance of the factors in the GLMM's was assessed by Wald $F$ tests. A posteriori comparisons for significant factors were carried out with Tukey tests. All statistical analyses were carried out with software $R$ (R Development Core Team 2010), using "nlme" package (Pinheiro et al. 2009).

\section{Results}

In 2008, we measured 480 live hatchlings from 24 different clutches, 37 hatchlings that died from stranding on the rocks in at least 14 independent occasions, and 208 hatchlings killed by ghost crabs in at least 28 independent occasions. For 2009, these numbers were as follows: 266 live hatchlings from 50 different clutches (out of these, 80 hatchlings from 40 different clutches were euthanized); 35 animals that died from stranding on the rocks in 10 independent episodes; 43 animals killed by ghost crabs in at least 22 independent occasions.

There were significant differences in hatchling carapace length (CL) among the different categories (killed by crabs, stranded in rocks or alive; GLMM, effect of category, $\left.F_{(2,138)}=8.8, p=0.0003\right)$, but not between the 2 years (GLMM, effect of year, $\left.F_{(1,138)}=0.8, p=0.37\right)$. A posteriori tests revealed that hatchlings killed by crabs were significantly smaller than both live and rock-stranded hatchlings (Fig. 2).

Euthanized hatchlings did not significantly change carapace length during the night (Paired $t$ test, $t_{12}=0.74$, $p=0.47$ ), and the same happened for hatchlings that were killed by ghost crabs early in the night and were remeasured in the early morning (Paired $t$ test, $t_{11}=1.76$, $p=0.11$.

\section{Sex determination}

Success on sex determination through histological examination was very high $(95 \%)$ for euthanized hatchlings and

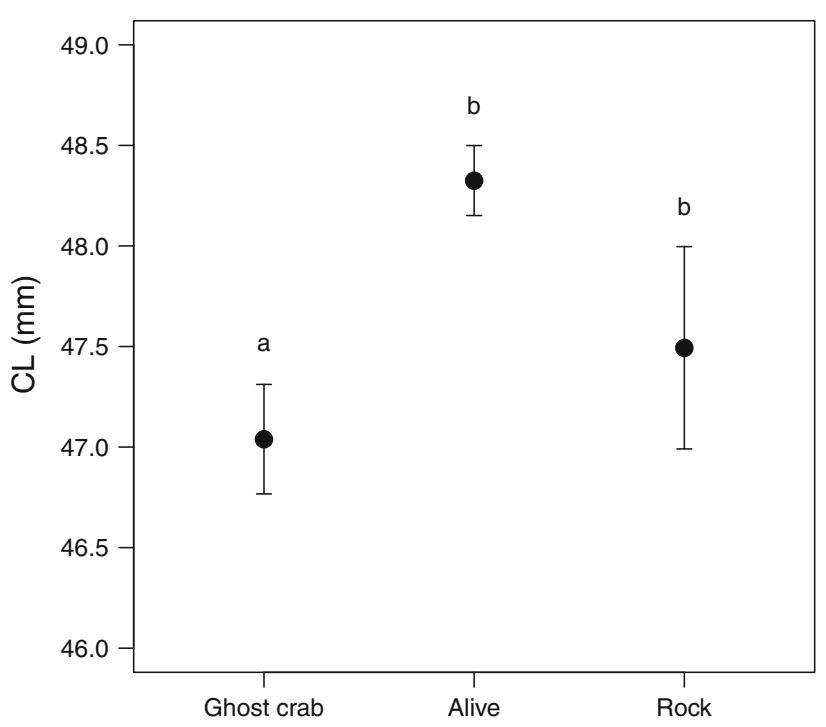

Fig. 2 Hatchling carapace length $(C L) \pm S E$, considering the three hatchling categories. Sample size (number of clutches) as follows: killed by ghost crabs $(N=50)$; alive $(N=74)$; stranded on rocks $(N=24)$. Different letters depict the groups formed by the Tukey tests 
somewhat lower for those stranded on the rocks $(75 \%$ in 2008 and $80 \%$ in 2009) and killed by ghost crabs (77\% in 2008 and $79 \%$ in 2009). Impossibility to determine sex was due mainly to gonad degradation.

Gonadal and paramesonephric ductal structures were similar to previous descriptions (Miller and Limpus 2003; Wibbels 2003), and there were no major difficulties in sex determination, with only two discrepancies between the two observers, both due to difficulties of interpretation of the paramesonephric duct. There were also no discrepancies in the 19 hatchlings for which both gonad/kidney complexes were used. The large majority of sex determinations $(84 \%)$ was based on the visualization of the gonad or of both gonad and paramesonephric duct; the remaining $16 \%$ relied on the paramesonephric duct alone.

\section{Hatchling sexual dimorphism and sex-ratios}

There were no differences in carapace length between sexes and years (two-way ANOVA: effect of sex, $F_{(1,73)}=0.17, p=0.68$; effect of year, $F_{(1,72)}=1.03$, $p=0.31$; Fig. 3). Furthermore, there were also no sexual differences in the other body dimensions measured in the euthanized hatchlings in 2009 (plastron length, $t_{42}=0.61$, $p=0.54$; carapace width, $t_{42}=0.53, p=0.59$; weight, $t_{43}=1.55, p=0.13$; Table 1).

The proportions of males in the clutches did not differ among different classes of mortality (GLM: effect of mortality cause, $z=0.79, p=0.43$ ), but there was a

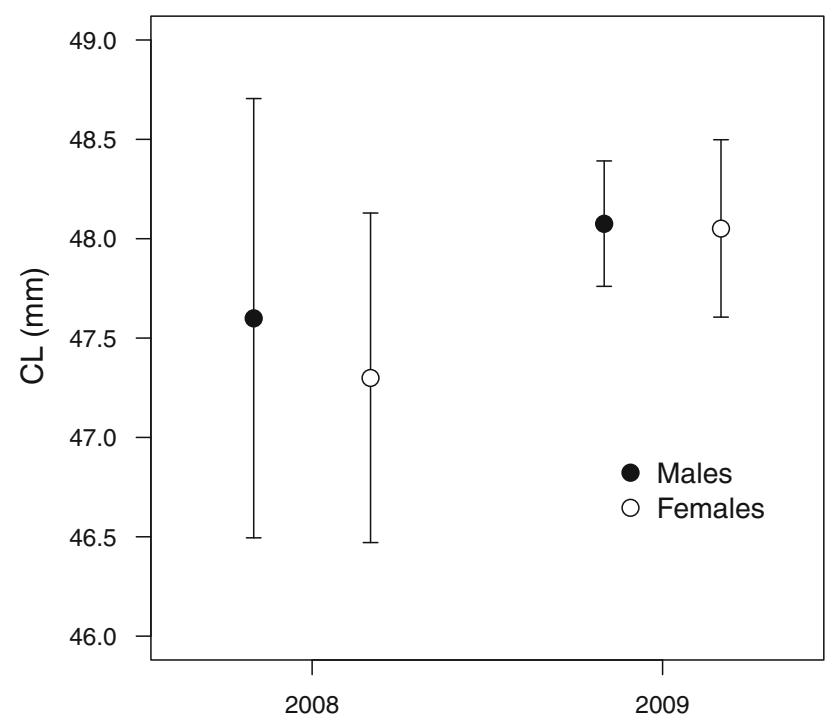

Fig. 3 Hatchling carapace length $(C L) \pm$ SE, considering both sexes and study years. Only one individual was considered from each clutch, except when a brood contained both sexes, in which case both a male and female hatchling were selected (see "Materials and methods"). The smaller 2008 sample accounts for the differences in standard error. There were no significant differences between sexes
Table 1 Hatchling dimensions \pm SD, considering individuals of both sexes that were euthanized in 2009. Only one individual was considered from each clutch, except when a brood contained both sexes, in which case both a male and female hatchling were selected (see "Materials and methods"). There were no significant sexual differences in any of the hatchling dimensions (see "Results")

\begin{tabular}{lll}
\hline & Females $(N)$ & Males $(N)$ \\
\hline Carapace width $(\mathrm{mm})$ & $39.7 \pm 1.8(22)$ & $39.4 \pm 1.5(22)$ \\
Plastron length $(\mathrm{mm})$ & $40.4 \pm 1.9(22)$ & $40.1 \pm 1.9(22)$ \\
Weight $(\mathrm{g})$ & $23.4 \pm 1.9(23)$ & $22.5 \pm 2.2(22)$ \\
\hline
\end{tabular}

Table 2 Proportion (\%) of males \pm SE, considering different causes of death and both study years. Sample size-number of clutches. The proportions of males differed only between and not within years (see "Results")

\begin{tabular}{lll}
\hline Cause of death & $2008(N)$ & $2009(N)$ \\
\hline $\begin{array}{l}\text { Random (rock-stranding/ } \\
\text { euthanization) }\end{array}$ & $18.1 \pm 8.0(13)$ & $47.6 \pm 7.3(43)$ \\
Predation by Ghost crab & $13.2 \pm 5.7(25)$ & $38.5 \pm 9.8(20)$ \\
Total & $14.9 \pm 5.8(38)$ & $44.7 \pm 6.3(63)$ \\
\hline
\end{tabular}

marked difference among the study years (GLM, effect of year, $z=2.94, p=0.003$ ). The sex-ratio was strongly biased towards females in 2008, while in 2009 the proportions of both sexes were more similar (Table 2).

\section{Discussion}

Our results demonstrate that it is possible to use hatchlings recently predated by ghost crabs for the estimation of the overall sex-ratios produced during a given period on a particular beach. We also showed that $O$. cursor selects hatchlings according to their size, but not according to their sex.

Size-based selection by $O$. cursor was an expected result, as several studies show that small turtle hatchlings are more vulnerable to predation (Janzen 1993; Gyuris 1994). With a cephalothorax length that may reach $5 \mathrm{~cm}$ and a leg span up to $20 \mathrm{~cm}$ (unpublished data), most O. cursor adults at Poilão are somewhat larger than the $\sim 5 \mathrm{~cm}$ hatchlings. Their known predation strategies include active chases (Glen et al. 2005) or waiting for the hatchlings at the shoreline (Mendonça et al. 2010). Our own observations suggest that both strategies may occur at Poilão, as we saw several partially buried crabs at prominent spots in the nesting areas with their eyes protruding from the sand, but also active crabs everywhere on the beach during the night. Ghost crabs are very fast runners, easily outrunning a man, and so we suspect that the 
increase in velocity that may be enabled by a large hatchling size (Ischer et al. 2009) may be ineffective as a protection from these crabs. However, as hatchling carapace length is positively related with flipper length (Burgess et al. 2006), large hatchlings will probably have an advantage over small hatchlings by being more difficult to control and/or being turned over (Janzen 1993; Myers et al. 2007), especially by predators of a similar size.

Our results depended on a particularity of the biology of $O$. cursor-its incomplete consumption of hatchling's bodies. In fact, most of the turtle carcasses were found decapitated with a hole pierced in the insertion of the neck, through which the crab removed the yolk sac, leaving most of the remaining carcass intact. Ghost crabs of the genus Ocypode have been documented before as predators of sea turtle nests (Ali and Ibrahim 2002; Varo-Cruz 2010) and hatchlings (Glen et al. 2005; Mendonça et al. 2010; Tomillo et al. 2010), but as far as we know, this partial hatchling consumption has only been indicated for Caretta caretta at Cape Verde (Delgado 2008). Delgado (2008) tried to use the recovered gonads to determine hatchling sex, but with poor success, due to the rapid decomposition of gonadal tissue (this was not verified in the present study). The feasibility of the use of hatchlings remains at Poilão is probably related with their very high abundance during a relatively long season in this island, which allows the ghost crabs to consume only the most energetically rich portion of the hatchling, namely the yolk sac.

Given the size-based prey selection by ghost crabs, the possibility to use hatchlings killed by this species to estimate sex-ratios is dependent on the absence of sexual dimorphism at hatching, which was documented here. Besides determining hatchling sex, incubation temperature is also known to influence other hatchling phenotypic traits, such as hatchling mass and size (Reece et al. 2002; Glen et al. 2003; Booth et al. 2004), or hatchling locomotion performance (Booth et al. 2004; Burgess et al. 2006; Ischer et al. 2009), and therefore, an association between sex and any one of the above-mentioned traits is possible. For C. mydas, a higher incubation temperature was shown to produce smaller hatchlings at Ascension island (Glen et al. 2003) and Australia (Booth et al. 2004; Ischer et al. 2009). However, a relationship between hatchling sex and size has not yet been shown in any particular nesting beach for any sea turtle, being only documented by comparing nesting beaches with different climates (Glen et al. 2003) or by manipulating the incubation temperature of translocated clutches (Reece et al. 2002; Booth et al. 2004). Several factors may explain the absence of a sex-based dimorphism documented in the present study. First, the main predictor of hatchling size is not temperature or other environmental parameters, but egg size (Glen et al. 2003; Burgess et al. 2006; Ischer et al. 2009; Pintus et al. 2009). Second, while hatchling sex is determined by the temperature to which the embryos were subjected during the thermo-sensitive period (approximately 1/3 of the incubation), size at hatching will be the result of the integration of the whole range of incubation temperatures, and so climatic variability after the thermo-sensitive period will easily mask any previously developed relationship between size and sex. In fact, Reece et al. (2002) showed that changing the incubation environment after sex determination leads to the production of differently sized hatchlings with the same sex.

Another important aspect of this work was how we obtained the sample of animals that died from random causes. This sample was composed by hatchlings stranded on the rocks (2008 and 2009) and by euthanized animals (2009). While the euthanized hatchlings were indeed sampled randomly, it is theoretically possible that the hatchlings that got stranded were somehow in bad condition. However, the very catastrophic nature of the deaths by stranding on the rocks, that sometimes leads to the death of entire clutches, points for a truly randomness of this process. Furthermore, and despite some evidence of the influence of the tidal cycle on nesting attempts by female sea turtles (Pike 2008), it is difficult to think of a way how the hatchlings could assess the tide cycle during emergence. In fact, studies assessing hatchling emergence patterns only found a relationship with sand temperatures (as an indication of the day or night period) (Glen et al. 2005; Glen et al. 2006).

Hatchling sex-ratios were nearly balanced in October 2009 and with an excess of females in November 2008. We estimate, based on known incubation periods for the whole reproductive season for this population (Catry et al. 2010), that the thermo-sensitive period of the 2009 sample took place during September, while for the 2008 sample, this happened during October, closer to the end of the rainy season (Fig. 1b). Rainfall decreases sand temperature on nesting beaches in tropical regions, having a marked cooling effect on nests (Houghton et al. 2007). Thus, and in spite of the relatively constant air temperature in the region during all the year (Fig. 1b), the 2009 sample was probably subjected to lower temperatures than the 2008 sample during their thermo-sensitive period, which may explain the differences in hatchling sex-ratios.

There are relatively few estimates of $C$. mydas sex-ratios under natural conditions, especially for tropical and subtropical regions. In the tropical Atlantic, Godfrey et al. (1996) reported 64\% females in clutches from Suriname (latitude $5^{\circ} \mathrm{N}$ ), and Godley et al. (2002) showed a $75 \%$ female production in Ascension Island (latitude $7^{\circ} \mathrm{S}$ ). The Poilão nests (latitude $10^{\circ} \mathrm{N}$ ) produced from 53 to $84 \%$ females, depending on the date of egg-laying, and these percentages will presumably be lower for earlier nests and higher for later ones. These values contrast with the 
extremely female-biased sex-ratios documented in the Mediterranean for C. mydas (e.g. Broderick et al. 2000) and indicate that for this tropical sea turtle there may be a pattern of increasing unbalance in sex-ratios with latitude, opposite to that documented for $C$. caretta (Witt et al. 2010), a species of subtropical/temperate seas. Our sexratio estimate for the clutches that were laid in August (the 2009 sample) shows one of the most balanced sex-ratios ever documented for this species.

The effects of rainfall on sea turtle sex-ratios have been documented in tropical and subtropical regions (Godfrey et al. 1996; Houghton et al. 2007), indicating that changes in the length of the rainy season may have consequences for sea turtle populations. Changes of this type have taken place in the West African Sudan-Sahel zone, with an approx. $40 \%$ reduction in average rainfall in the last decades of the twentieth century, when compared to midcentury values (Bell and Lamb 2006). The territory of Guinea-Bissau is located in the transition between wet and dry climates and is, therefore, vulnerable to small shifts in the distribution patterns of rainfall, which may have implications for the long-term reproductive biology and the very viability of these populations.

Sea turtle hatchling sex-ratios are difficult to estimate, especially in remote areas. Recording incubation duration of several nests is dependent on a continued presence at the nesting beaches; furthermore, estimation inaccuracies are inevitable for nests close to the pivotal values, and inaccuracies of $10 \%$ have been considered acceptable (Mrosovsky et al. 1999). The less labour-demanding use of temperature loggers to register nest temperatures may become an expensive method, and even temperature loggers (just as incubation durations) will provide poor sexratio estimates when nest temperatures fluctuate around the pivotal temperature during the thermo-sensitive period, a common event in the wet tropics due to the dependence of sand temperature on rainfall. At Poilão, both predated and rock-stranded hatchlings may be used to estimate sexratios, and this method is probably feasible in other areas, particularly in beaches with high nesting intensities that attract similar or different arrays of predators. Ghost crabs may depict predation biases that went undetected during this study, but the evidence presented here suggests these biases must be small. Considering the difficulty of obtaining good estimates of sex-ratios by other methods, the use of hatchlings killed by ghost crabs may provide a practical mean of obtaining data of enough quality to document and monitor broad temporal and spatial trends in this trait, with relevance for studies of evolutionary ecology and for conservation.

Acknowledgments Our work on sea turtle sex-ratios on Poilão is supported by Project 09/74 of MAVA-Fondation pour la Nature, by
Project 77340-000 of IUCN-International Union for Nature Conservation and by FCT-Fundação para a Ciência e a Tecnologia (Portugal) through Programa Plurianual (UI\&D 331/94). We also thank the support by the "Fondation Internationale du Banc d'Arguin" (FIBA). Permits were issued by IBAP-Instituto para a Biodiversidade e Áreas Protegidas of Guiné-Bissau. Authorization for euthanization of a sample of hatchlings in 2009 was obtained from the IBAP and the João Vieira and Poilão Marine National Park Direction. P. Segurado draw Fig. 1a. We thank the comments of two reviewers and are grateful to Thierry Renaud and Mathieu Ducroq for support and encouragement, for the support of the National Park staff João Pereira, Santinho, Rofico, António Baca, César Banca, and especially of the IBAP Director, Alfredo Simão da Silva.

\section{References}

Ali A, Ibrahim K (2002) Crab predation on green turtle (Chelonia mydas) eggs incubated on a natural beach and in turtle hatcheries. Proceedings of the 3rd workshop on SEASTAR2000, Graduate School of Informatics, Kyoto University, pp 95-100

Bell MA, Lamb PJ (2006) Integration of weather system variability to multidecadal regional climate change: the West African SudanSahel zone, 1951-98. J Climate 20:5343-5365. doi:10.1175/ JCLI4020.1

Bolten AB (1999) Techniques for measuring sea turtles. In: Eckert KL, Bjorndal KA, Abreu-Grobois FA Donnelly M (eds) Research and management techniques for the conservation of sea turtles. IUCN/SSC Marine Turtle Specialist Group Publication 4, Blanchard, pp 110-115

Booth DT, Burgess E, McCosker J, Lanyon JM (2004) The influence of incubation temperatures on post-hatching fitness characteristics of turtles. Int Congr Ser 1275:226-233

Broderick AC, Godley BJ, Reece S, Downie JR (2000) Incubation periods and sex ratios of green turtles: highly female biased hatchling production in the eastern Mediterranean. Mar EcolProg Ser 202:273-281. doi:10.3354/meps202273

Burgess EA, Booth DT, Lanyon JM (2006) Swimming performance of hatchling green turtles is affected by incubation temperature. Coral Reefs 25:341-349. doi:10.1007/s00338-006-0116-7

Catry P, Barbosa C, Indjai B, Almeida A, Godley BJ, Vié J (2002) First census of the green turtle at Poilão, Bijagós Archipelago, Guinea-Bissau: the most important nesting colony on the Atlantic coast of Africa. Oryx 36:400-403. doi:10.1017/S003060 5302000765

Catry P, Barbosa C, Paris B, Indjai B, Almeida A, Limoges B, Silva C, Pereira H (2009) Status, ecology and conservation of sea turtles in Guinea-Bissau. Chelonian Conserv Biol 8:150-160. doi:10.2744/CCB-0772.1

Catry P, Barbosa C, Indjai B (2010) Marine turtles of Guinea-Bissau. Status, biology and conservation. Instituto da Biodiversidade e das Áreas Protegidas, Bissau

Ceriani SA, Wyneken J (2008) Comparative morphology and sex identification of the reproductive system in formalin-preserved sea turtle specimens. Zoology 111:179-187. doi:10.1016/j.zool. 2007.07.007

Chaloupka M, Kamezaki N, Limpus C (2008) Is climate change affecting the population dynamics of the endangered Pacific loggerhead sea turtle? J Exp Mar Biol Ecol 356:136-143. doi: 10.1016/j.jembe.2007.12.009

Delgado C (2008) Gonad development and hormone titres in loggerhead sae tutles (Caretta caretta) in the NE Atlantic. Dissertation, Universidade da Madeira, Funchal

Ewert MA, Nelson CE (1991) Sex determination in turtles: diverse patterns and some possible adaptive values. Copeia 1991:50-69 
Fortes O, Pires AJ, Bellini C (1998) Green turtle, Chelonia mydas, in the island of Poilão, Boloma-Bijagós Archipelago, GuineaBissau, West Africa. Marine Turt Newsl 80:8-10

Glen F, Mrosovsky N (2004) Antigua revisited: the impact of climate change on sand and nest temperatures at a hawksbill turtle (Eretmochelys imbricata) nesting beach. Glob Change Biol 10:2036-2045. doi:10.1111/j.1529-8817.2003.00865.x

Glen F, Broderick AC, Godley BJ, Hays GC (2003) Incubation environment affects phenotype of naturally incubated green turtle hatchlings. J Mar Biol Assoc UK 83:1183-1186. doi: 10.1017/S0025315403008464h

Glen F, Broderick AC, Godley BJ, Hays GC (2005) Patterns in the emergence of green (Chelonia mydas) and loggerhead (Caretta caretta) turtle hatchlings from their nests. Mar Biol 146:1039-1049. doi:10.1007/s00227-004-1492-6

Glen F, Broderick AC, Godley BJ, Hays GC (2006) Thermal control of hatchling emergence patterns in marine turtles. J Exp Mar Biol Ecol 334:31-42. doi:10.1016/j.jembe.2006.01.005

Godfrey MH, Barreto R, Mrosovsky N (1996) Estimating past and present sex ratios of sea turtles in Suriname. Can $\mathrm{J}$ Zool 74:267-277. doi:10.1139/z96-033

Godley BJ (2009) Incorporating climate change into endangered species conservation: Introduction. Endanger Species Res 7:85-86. doi:10.3354/esr00203

Godley BJ, Broderick AC, Glen F, Hays GC (2002) Temperaturedependent sex determination of Ascension Island green turtles. Mar Ecol-Prog Ser 226:115-124. doi:10.3354/meps226115

Gross TS, Crain DA, Bjorndal KA, Bolten AB, Carthy RR (1995) Identification of sex in hatchling loggerhead turtles (Caretta caretta) by analysis of steroid concentrations in chorioallantoic/ amniotic fluid. Gen Comp Endocr 99:204-210. doi:10.1006/gcen. 1995.1103

Gyuris E (1994) The rate of predation by fishes on hatchlings of the green turtle (Chelonia mydas). Coral Reefs 13:137-144. doi: 10.1007/BF00301189

Houghton JD, Myers AE, Lloyd C, King RS, Isaacs C, Hays GC (2007) Protracted rainfall decreases temperature within leatherback turtle (Dermochelys coriacea) clutches in Grenada, West Indies: ecological implication for a species displaying temperature dependent sex determination. J Exp Mar Biol Ecol 345:71-77. doi:10.1016/j.jembe.2007.02.001

Ischer T, Ireland K, Booth DT (2009) Locomotion performance of green turtle hatchlings from the Heron Island Rookery, Great Barrier Reef. Mar Biol 156:1399-1409. doi:10.1007/s00227 -009-1180-7

Janzen FJ (1993) An experimental analysis of natural selection on body size of hatchling turtles. Ecology 74:332-341. doi: $10.2307 / 1939296$

Kamel SJ, Mrosovsky N (2006) Deforestation: risk of sex ratio distortion in hawksbill sea turtle. Ecol Appl 16:923-931. doi: 10.1890/1051-0761(2006)016[0923:DROSRD]2.0.CO;2

Kaska Y, Ilgaz Ç, Özdemir A, Baskale E, Türkozan O, Baran I, Stachowitsch M (2006) Sex ratio estimations of loggerhead sea turtle hatchlings by histological examination and nest temperatures at Fethiyes beach, Turkey. Naturwissenschaften 93:338-343. doi:10.1007/s00114-006-0110-5

Mendonça VM, Saady SA, Kiyumi AA, Erzini K (2010) Interactions between Green Turtles (Chelonia mydas) and Foxes (Vulpes vulpes arabica, $V$. rueppellii sabaea, and $V$. cana) on turtle nesting grounds in the Northwestern Indian Ocean: impacts of the fox community on the behavior of nesting sea turtles at the Ras Al Hadd turtle reserve, Oman. Zool Stud 49:437-452

Merchant-Larios H, Ruiz-Ramirez S, Moreno-Mendoza N, Marmolejo-Valencia A (1997) Correlation among thermosensitive period, estradiol response, and gonad differentiation in the sea turtle Lepidochelys olivacea. Gen Comp Endocr 107:373-385. doi:10.1006/gcen.1997.6946

Miller JD, Limpus CJ (2003) Ontogeny of marine turtle gonads. In: Lutz PL, Musick JA, Wyneken J (eds) The biology of sea turtles. CRC Press, Boca Raton, pp 199-224

Mrosovsky N, Benabib M (1990) An assessment of two methods of sexing hatchling sea turtles. Copeia 1990:589-591

Mrosovsky N, Bapistotte C, Godfrey H (1999) Validation of incubation duration as an index of the sex ratio of hatchling sea turtles. Can J Zool 77:831-835. doi:10.1139/z99-039

Myers EM, Tucker JK, Chandler CH (2007) Experimental analysis of body size and shape during critical life-history events of hatchling slider turtles, Trachemys scripta elegans. Funct Ecol 21:1106-1114. doi:10.1111/j.1365-2435.2007.01337.x

Pike DA (2008) Environmental correlates of nesting in loggerhead turtles, Caretta caretta. Anim Behav 76:603-610. doi:10.1016/ j.anbehav.2008.04.010

Pinheiro J, Bates D, DebRoy S, Sarkar D, R Core team (2009) nlme: Linear and Nonlinear Mixed Effects Models. R package version 3.1-96. http://CRAN.R-project.org/package $=$ nlme

Pintus KJ, Godley BJ, McGowan A, Broderick AC (2009) Impact of clutch relocation on green turtlte offspring. J Wildl Manage 73:1151-1157. doi:10.2193/2008-103

R Development Core Team (2010) R: a language and environment for statistical computing. R Foundation for Statistical Computing, Vienna

Reece S, Broderick A, Godley B, West S (2002) The effects of incubation environment, sex and pedigree on the hatchling phenotype in a natural population of loggerhead turtles. Evol Ecol Res 4:737-748

Stocker L (2005) Practical wildlife care, 2nd edn. Blackwell, Oxford

Toland B (1991) Great horned owl predation of Atlantic loggerhead turtle hatchlings. Fla Field Nat 19:117-119

Tomillo P, Paladino F, Suss J, Spotila J (2010) Predation of leatherback turtle hatchlings during the crawl to the water. Chelonian Conserv Biol 9:18-25. doi:10.2744/CCB-0789.1

Tureli C, Duysak O, Akamca E, Kiyagi V (2009) Spatial distribution and activity pattern of the ghost crab, Ocypode cursor (L., 1758) in Yumurtalik Bay, North-Eastern Mediterranean-Turkey. J Anim Vet Adv 8:165-171

Varo-Cruz N (2010) Biología reproductora de la tortuga boba (Caretta caretta Linneus, 1758) en la isla de Boavista, archipiélago de Cabo Verde. Dissertation, Universidad de Las Palmas de Gran Canaria

Wibbels T (2003) Critical approaches to sex determination in sea turtles. In: Lutz PL, Musick JA, Wyneken J (eds) The biology of sea turtles. CRC Press, Boca Raton, pp 103-134

Wibbels T, Owens DW, Limpus CJ (2000) Sexing juvenile sea turtles: is there an accurate and practical method? Chelonian Conserv Biol 3:756-761

Witt M, Hawkes L, Godfrey M, Godley B, Broderick A (2010) Predicting the impacts of climate change on a globally distributed species: the case of the loggerhead turtle. J Exp Biol 213:901-911. doi:10.1242/jeb.038133

Wyneken J, Epperly SP, Crowder LB, Vaughan J, Esper KB (2007) Determining sex in posthatchling loggerhead sea turtles using multiple gonadal and accessory duct characteristics. Herpetologica 63:19-30. doi:10.1655/0018-0831(2007)63[19:DSIPLS] 2.0.CO;2

Zbinden JA, Christina D, Margaritoulis D, Arlettaz R (2007) Large spatial variation and female bias in the estimated sex ratio of loggerhead sea turtle hatclings of a Mediterranean rookery. Endanger Species Res 3:305-312. doi:10.3354/esr00058 
Copyright of Marine Biology is the property of Springer Science \& Business Media B.V. and its content may not be copied or emailed to multiple sites or posted to a listserv without the copyright holder's express written permission. However, users may print, download, or email articles for individual use. 